\title{
The application of water poverty mapping in water management
}

\author{
C VAN DER VYVER AND DBJORDAAN
}

\begin{abstract}
Water management has been carried out for many centuries wherever there has been a need to provide water to large numbers of people. Complex social norms have developed around water management and competing users have established political (governance) and economic cooperative relationships. For example, community-managed irrigation schemes in Bali and the cloud-collection canals built by the Incas at Inca Pirca in Peru are examples of water management systems which still currently supply water to people (Sullivan et al., 2005).

Water resources will steadily decline because of population growth, pollution and expected climate change (Hemson et al., 2008). It has been estimated that the global demand for water doubles approximately every two decades (Meyer, 2007) and that water will even become as expensive as oil in the future (Holland, 2005). "In the year 2000, global water use was twice as high as it was in 1960" (Clarke and King, 2004:19). Unfortunately this trend is expected to continue.

The aim of this paper is to describe how water poverty mapping as a process can be used to assist the management of our already scarce water resources. It constructs a water poverty map after which it describes its application at various management levels. The research indicates that the mapping process can be used to obtain more accurate predictions, as well as to form part of the master plan and integrated development plan documents.
\end{abstract}

Keywords: Water management, water poverty mapping.

Disciplines: Water management, geographical information systems (GIS), poverty studies, decision support.

\section{Introduction}

In recent years it has been widely recognised that water was managed with little regard to the efficiency of its utilisation and with no or very little effective pollution control (Pallett, 1997).

1. Dr Charles van der Vyver and Prof. Dawid Jordaan are members of the academic staff in the School of Information Technology, Faculty of Economics and Information Technology at North-West University (NWU), Vaal, Vanderbijlpark, South Africa. Their respective emails are: Charles.vandervyver@nwu.ac.za and Dawid.jordaan@nwu.ac.za. This paper is based on a thesis that was completed as part of a PhD degree in July 2011 at the Vaal Triangle Campus of the North-West University in South Africa. 
South Africa, being a water-stressed country with less than $1700 \mathrm{~m}^{3}$ of water for each person per year (Rand Water, 2008), has limited fresh water resources and budgets for the supply of basic infrastructure services. Currently over 6 million people in South Africa are without access to even a basic level of water supply or have only a very limited level of access (Cullis, 2005).

The norm has been to think of water poverty purely in terms of a lack of the actual resource; however, Sullivan et al. (2003) and Sullivan et al. (2005) have shown that water poverty should be expressed in terms of resource, access, capacity, use and environment. These five components are contained in the Water Poverty Index (WPI) as developed by Sullivan et al. (2002), and refined by researchers at the Centre for Ecology and Hydrology in Wallingford, United Kingdom.

Graphical representations of the WPI are a very effective and understandable way of communicating information to the various stakeholders and role players, as no knowledge of the underlying data and its transformation is required. These graphical representations of the WPI are known as water poverty maps.

\section{Demarcation}

South Africa is a water-stressed country (Rand Water, 2008). Water stress is an indicator that is commonly used to measure the degree of water resources vulnerability, and typically occurs when the demand for water exceeds the supply (Perveen and James, 2011). Water stress causes deterioration of fresh water resources in terms of quantity and quality. Figure 1 shows the percentage of the world population living in each of the five water availability categories.

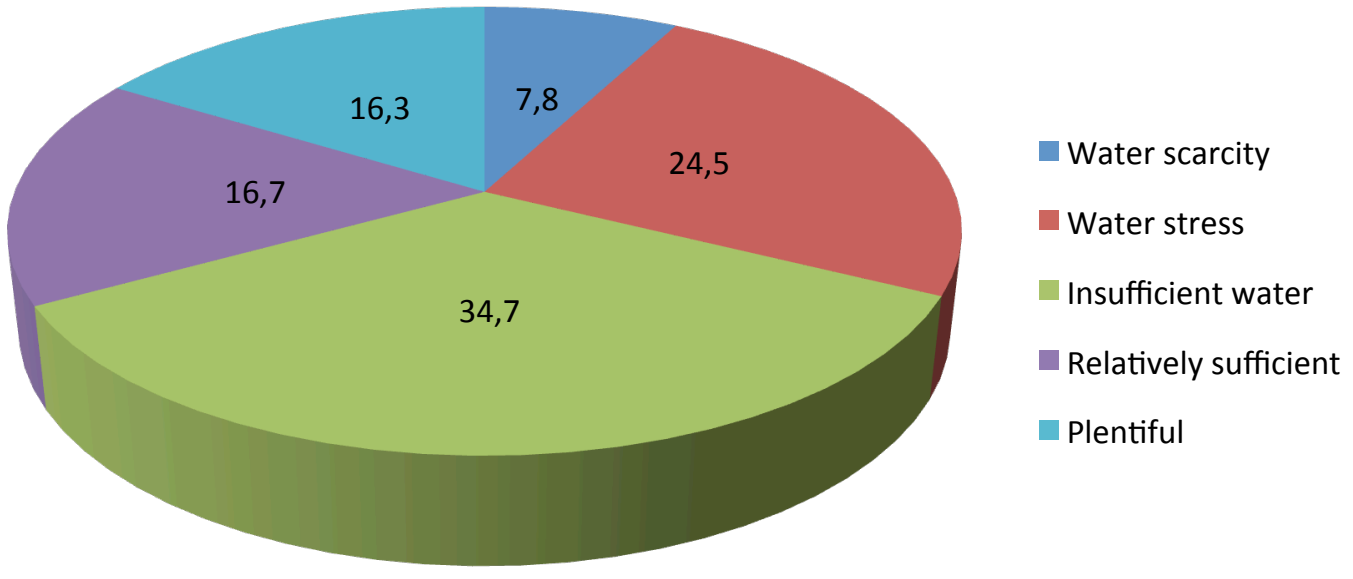

Figure 1 Percentage of the world population living in each of the five water availability categories (Source: Clarke and King, 2004)

Water scarcity occurs when a large number of people in an area do not have access to safe and affordable water to satisfy their needs for drinking, washing or their livelihoods for a significant period of time (Rijsberman, 2005). Rand Water (2008) warns that if South Africans do not learn how to use their limited water supplies wisely, they will move into a water scarcity category - that is, less than $1000 \mathrm{~m}^{3}$ per person per year - by 2025. On a 
worldwide scale the World Bank estimates that roughly 166 million people in 18 countries are affected by water scarcity and another 270 million people in 11 countries are water stressed (Hemson et al., 2008).

This research addresses some of the various needs that were highlighted in the 1994 Reconstruction and Development Program (RDP), which listed "meeting basic needs" as one of its five broad programmes (Melville and Goddard, 1996). Some of the areas that were highlighted in the RDP as being extremely relevant, and therefore in need of research include, amongst others:

- Water, including its provision, sanitation and conservation.

- The environment.

- Social welfare.

This paper, either directly or indirectly, assists in addressing all of these needs.

Water poverty maps can be developed on almost any scale depending on the requirements, available financial resources and manpower (Cullis, 2002; 2005). The water poverty map will be constructed for the three towns and neighbouring townships that form the Vaal Triangle, namely Vanderbijlpark, Vereeniging and Sasolburg. Vanderbijlpark and Vereeniging are located right on the southern border of the Gauteng Province and Sasolburg is located right on the northern border of the Free State Province in South Africa.

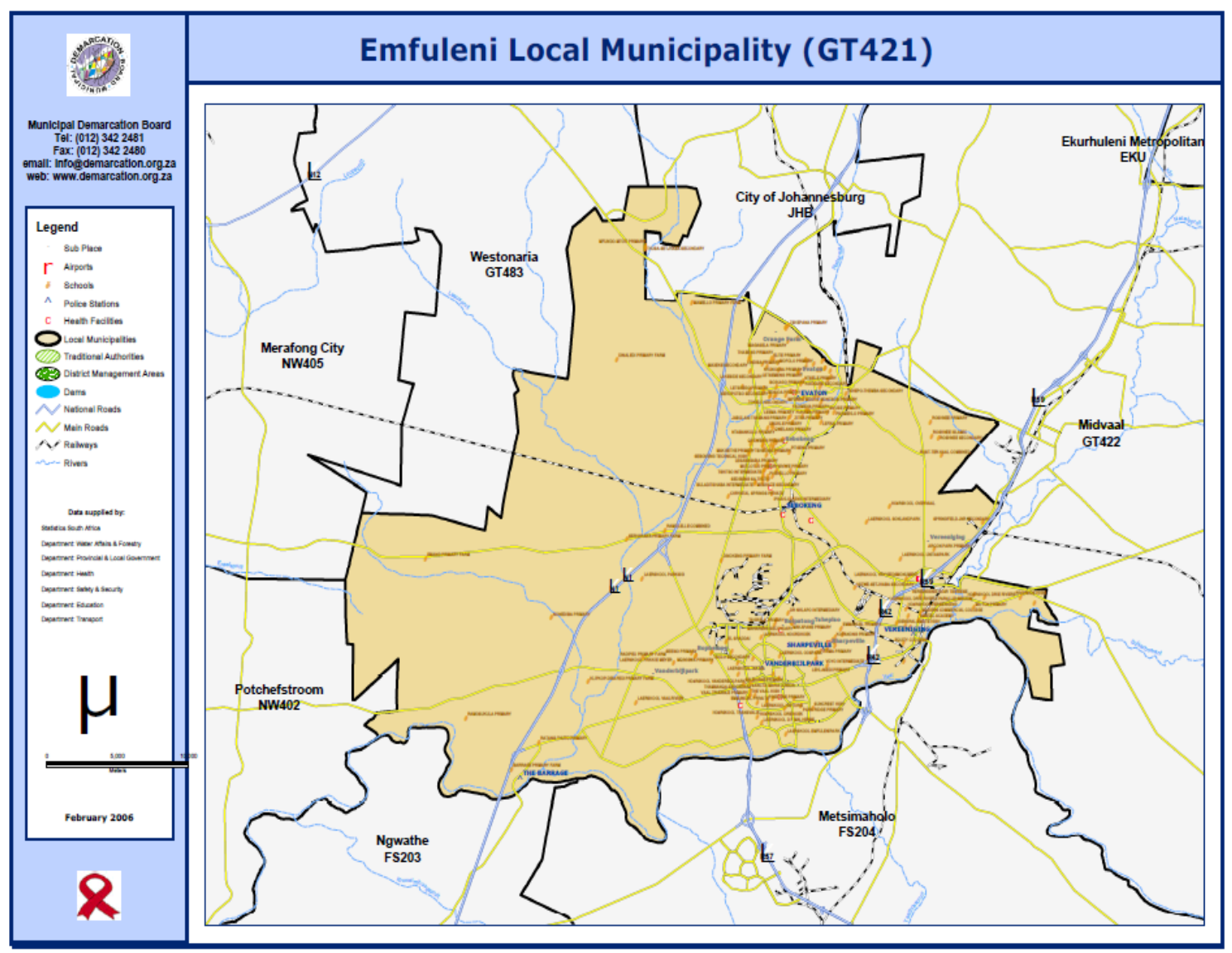

Figure 2 Boundaries of the Emfuleni local municipality(Source: Municipal Demarcation Board http://www.demarcation.org.za) 
One of the two local municipalities in the demarcated area is the Emfuleni local municipality (ELM). The ELM consists of the two main towns Vanderbijlpark and Vereeniging, along with their surrounding townships and settlements. Figure 2 illustrates the municipal boundaries of the ELM.

The other municipality in the area is the Metsimaholo local municipality (MLM), which consists mainly of the town Sasolburg, along with its surrounding townships and settlements. Figure 3 illustrates the municipal boundaries of the MLM.

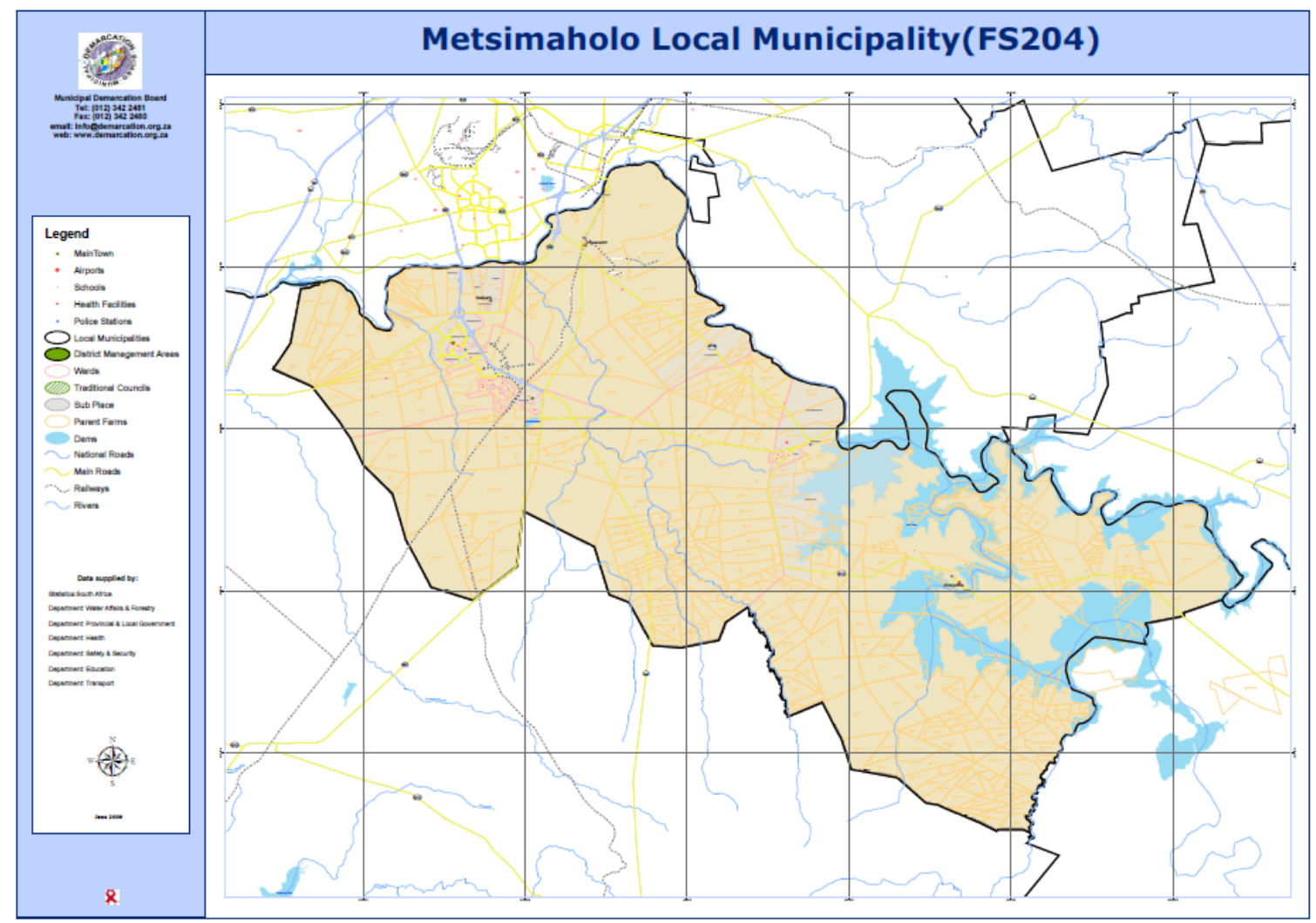

Figure 3 Boundaries of the Metsimaholo local municipality (Source: Municipal Demarcation Board http://www.demarcation.org.za)

The ELM has highlighted some challenges that they foresee with regards to their water and sanitation services. These challenges include:

- An ageing water infrastructure.

- A limited preventative maintenance program due to a shortage of personnel.

- Rapid development.

- Flat rate billing for water consumption in certain areas.

- Un-metered areas.

In the ELM area, Metsi-a-Lekoa is responsible for the distribution of potable water, the collection and conveyance of wastewater, and the treatment of the wastewater. Metsi-ALekoa is the dedicated water services authority entity for the ELM and its core functions are 
the water and sanitation functions of the municipality. They utilize some of the assets of the municipality to accomplish these tasks, and are also responsible for the maintenance and the costs of the water services systems (ELM, 2010). The water system consists of a small potable water treatment plant, 10 low level reservoirs, and the pipe networks. The sanitation system consists of gravity pipelines, and 48 sewage pump stations and their pumping mains. The wastewater treatment system consists of 3 wastewater treatment works. The Sebokeng facility is the largest works with a capacity of $116 \mathrm{M \ell} /$ day, the second largest works is the Leeuwkuil facility with a capacity of $32 \mathrm{M}$ /day, and the smallest works is the Rietspruit facility with a capacity of $23 \mathrm{Ml} /$ day (ELM, 2010).

As in the rest of South Africa, unemployment continues to remain a problem in the Vaal Triangle. This leads to high poverty levels and a high dependency ratio within the municipality, which directly hampers the ability of the population to save and/or engage in other entrepreneurship activities (ELM, 2010). The dependency ratio refers to the amount of unemployed people depending on the municipality for basic services, without being able to pay for it or without making any sort of economical contribution. Ideally, this ratio should be as close as possible to 0. Figure 4 illustrates the employment profile of the ELM. "Unemployed" refers to people aged between 16 and 65 who are currently looking for a job opportunity, and "not economically active" refers to people who are employable but who are not currently looking for a job opportunity.

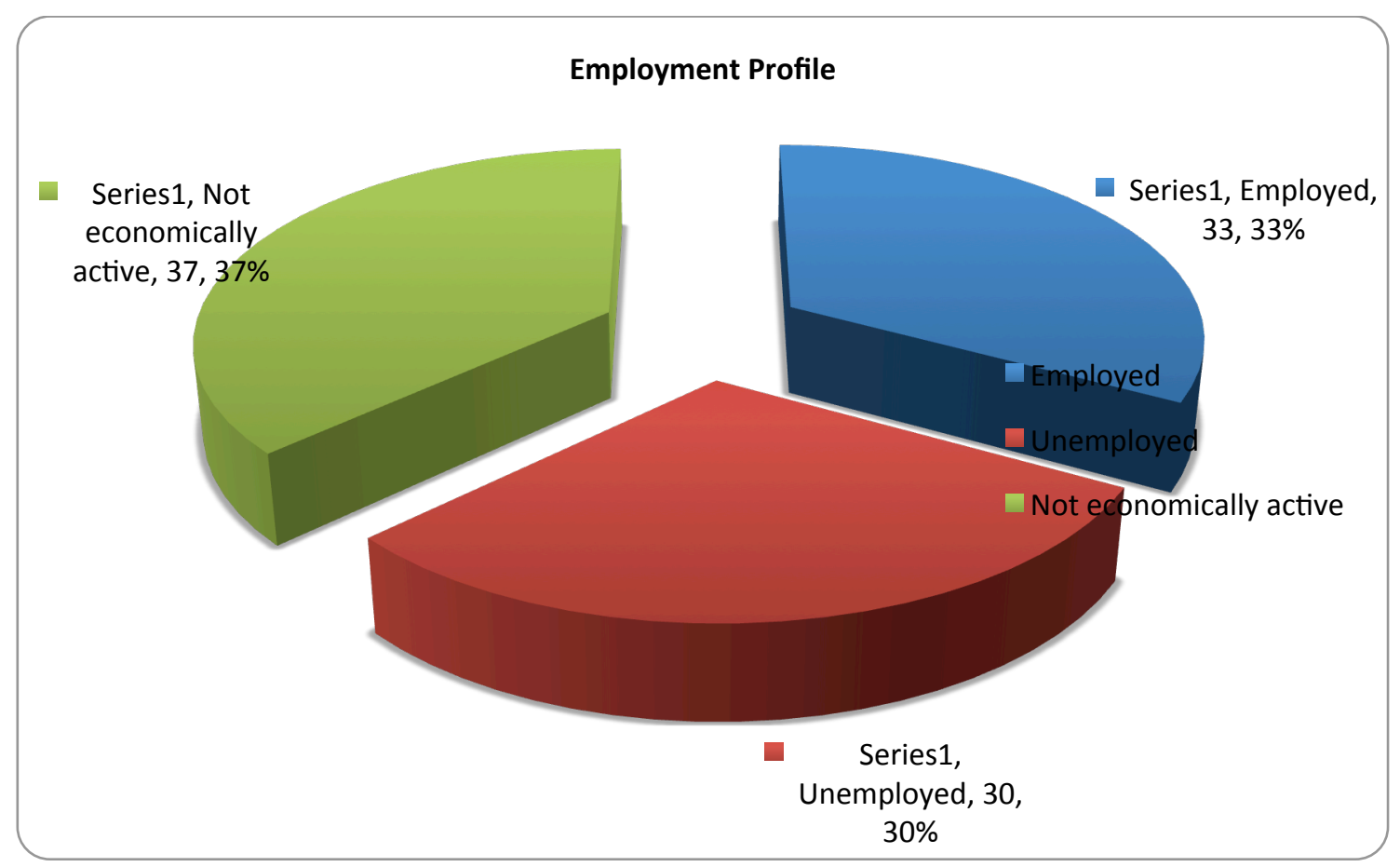

Figure 4 Emfuleni local municipality employment profile (Source: Emfuleni Local Municipality, 2010)

The economic growth for the municipality has been quite slow when compared to the targets that were set for the region by the Gauteng Growth and Development Strategy (GGDS). For the period from $1995-2000$ the growth rate was $0.4 \%$, for $2000-2006$ it was $1.8 \%$, and for the period from $2006-2011$ it is projected to be 1.1\% (ELM, 2010). 


\section{Research methodology}

This research is an example of mixed methods research. Mixed methods research combines or mixes quantitative research and qualitative research in the same study or a series of studies (Swanson and Holton, 2005). It evolved from researchers who started realising that aspects from both quantitative and qualitative research were required in order for them to answer their research questions. This view is supported by Onwuegbuzie and Leech (2005), who also argue that a combination of both methodologies should be used as both have inherent strengths and weaknesses. According to Warfield (2010), mixed methods research is a three stage process, namely:

1. Determine whether the study is a confirmatory or exploratory study.

2. Determine the type of data collection and operation.

3. The type of data analysis and inference.

Researchers that apply mixed methods research are referred to as pragmatic researchers by Onwuegbuzie and Leech (2005). According to them pragmatic researchers enjoy the following advantages over mono-method (purely quantitative or qualitative) researchers:

- More likely to promote collaboration among researchers, regardless of philosophical orientation.

- Flexibility in their investigative techniques.

- Having the opportunity to combine the macro and micro levels of a research issue.

- More likely to view research as a holistic endeavour.

- More able to combine empirical precision with descriptive precision.

- In a better position to use qualitative research to inform the quantitative portion of research studies, and vice versa.

It combines aspects from quantitative research, in terms of some of the statistical analysis performed and some of the data sources used, as well as aspects from qualitative research, in terms of choosing the case study approach and some of the data collection. When the three stages of mixed methods research as discussed above is considered, this research:

1. Is an exploratory study. Unlike with the confirmatory study, this research does not test the validity of an existing theory. It uses the WPI and water poverty mapping (WPM) to explore and document the levels of water poverty in the demarcated area of this study.

2. Uses open-ended interviews as its data collection method for its primary data and uses data sources that have been compiled by the Census Bureau and the Department of Water Affairs (DWA) for its secondary data. Primary data analysis refers to the analysis of data that has been collected as part of the study, and secondary data analysis refers to the analysis of data that has been collected previously. According to Doolan and Froelicher (2009), the use of secondary data analysis is appropriate if an existing data set is suitable for answering new research questions as the research can then be completed in less time and for less money. According to Melville and Goddard (1996) one of the major advantages of using interviews as a data collection method is that one can clarify answers and can follow up on interesting answers. This research used interviews to obtain the values for the resource component of the WPI, 
and to obtain the possible uses of the final water poverty map. The access, capacity, use and environment components of the WPI were calculated using existing sources, namely Census data and the Water Situation Assessment Model (WSAM) from the DWA.

3. Uses a case study for its data analysis to calculate the WPI and to construct the WPM for the demarcated area. The value of this research lies in the inferences that can be drawn regarding the use of the WPI and WPM by management to aid with the alleviation of water poverty.

The advantages of a case study as a research strategy include (Denscombe, 2003):

- It allows the researcher to deal with the subtleties and intricacies of complex situations.

- It allows the use of a variety of research methods.

- It fosters the use of multiple sources of data.

- It is suitable for when the researcher has little control over events.

- Concentrates effort on one research site.

- Suitable to both theory-building and theory-testing research.

According to Warfield (2010), Information Systems/Information Technology (IS/IT) research typically involves both technology and business, and this invariably leads to the combining of different disciplines and paradigms. To achieve good research, researchers should follow the standards of the scientific method to generate dependable data through professionally conducted practices (Swanson and Holton, 2005). According to Galliers and Land (1987), research in an applied topic or field can be considered successful when the knowledge that has been obtained through the research can be applied successfully in practice.

\section{Water management}

During recent years some of the major shortcomings of national water management that have been widely recognised (Clarke and King, 2004; Langford, 2005; Meyer, 2007; Pallett, 1997) include very little or no pollution control, and inefficient utilisation. According to Pallett (1997), the aim of water management should be to supply people with essential water supplies while ensuring that water continues to be shared among all the components of the human and natural environment in a river basin. The importance of good water management is vital in determining the water fate of the majority of the world's population (Clarke and King, 2004).

Management is one of the major problems in the global water sector (Ahmad, 2003), and according to Langford (2005), the reasons why we currently find ourselves in a water and sanitation crisis are:

- Insufficient and decaying infrastructure for water service delivery, especially in deprived rural and urban areas.

- Insufficient capacity and funding for the expansion and maintenance of water supply systems. 
- Pollution of traditional water sources, particularly from industrial waste, agricultural runoff and human and animal waste.

- Reduced access to, and depletion of, water resources due to drought, population growth, armed conflict and the dominance of commercial agricultural and industrial activities.

Many researchers (Ahmad, 2003; Cullis, 2005; Sullivan, 2002) suggest that a shift of emphasis to a more holistic approach to water management is necessary. As a first step, the concept of an Integrated Water Resource Management (IWRM) as a holistic approachedbased framework for water management was introduced. This approach focuses on poverty reduction and sustainability of ecosystems among other things; in other words to achieve a sustainable water world. The Global Water Partnership (2000:15) defines IWRM as " $a$ process which promotes the co-ordinated development and management of water, land, and related resources in order to maximise the resultant economic and social welfare in an equitable manner without compromising the sustainability of vital ecosystems".

At the United Nations Conference on the Environment and Development that was held in 1992 in Rio de Janeiro, IWRM was a major item on the agenda. During this conference the various stakeholders came up with an action plan for the world environmental crisis, called Agenda 21. Under this agenda, the four main objectives of IWRM are (Pallett, 1997):

1. To plan the sustainable and rational utilisation, protection, conservation and management of water resources.

2. To identify and strengthen or develop, as required, in particular in developing countries, the appropriate institutional, legal and financial mechanisms to ensure that water policy and its implementation are a catalyst for sustainable social progress and economic growth.

3. To promote a dynamic, iterative, interactive and multisectoral approach to water resources management.

4. To design, implement and evaluate projects and programmes that are both economically efficient and socially appropriate within clearly defined strategies.

Unfortunately, according to Swatuk (2010), although supporting the principle of IWRM, South Africa will experience some difficulties in realising the ideals of IWRM in practice. Examples of some of the contributing factors to these expected difficulties include:

- The loss of more than 1000000 jobs in the first post-apartheid decade, which had resulted in major economic implications.

- Fault lines that have appeared within and between the major political parties.

- Capital flight and the out-migration of skilled workers to other countries, which limit the capacity of the state and society to shift toward more efficient, equitable and sustainable processes of wealth creation.

Hemson et al. (2008) have analysed many years of work and development in the global water sector. This analysis has led them to compile the following set of guidelines, which, when adhered to, will greatly improve the effectiveness of any water management entity's efforts:

- Set lower goals, as sufficient funding will not be available, rather than argue strongly for more resources. 
- Emphasise the very simplest level of technology with wells and village hand pumps to make local water resources more available to the poor within existing budgets.

- Place responsibility first on communities and second on national governments rather than on international organisations.

- Place the responsibility for initial capital resources on communities and require communities to be responsible for operations and maintenance.

- Make water provision an aspect of community development rather than a public health issue.

- Seek ways in which more can be achieved with more or less the same financial commitment by fixing systems rather than providing greater funding.

- Pay greater attention to the role of women in managing water resources and benefiting from delivery.

- Stress better utilisation of water to improve health conditions, for example personal hygiene and proper sanitation.

Perhaps one of the most well-known examples of poor water management relates to the Aral Sea in Kazakhstan and Uzbekistan. The Aral Sea has shrunk by $66 \%$ in volume and by $50 \%$ in area since 1957, due to the diversion of two rivers that used to feed it for irrigation by the 1960's Soviet government (Clarke and King, 2004). The water level of the Aral Sea has dropped by more than 13 metres, and its mineral content has increased fourfold, which has effectively killed off the entire fish population. It went from a sea supporting 60000 fishermen in producing 40000 tons of fish, to a poisoned wasteland with no fish production. About half the populations of the once seaside Aral towns and villages have fled, leaving the people who were forced to stay in a constant battle with a deadly mix of pollutants. The infant mortality rate in the Aral region is among the highest in the world (Clarke and King, 2004).

\section{The water poverty index}

The conventional methods to assess water management were purely deterministic, relying on the availability of large-scale data. A method that is easy to calculate, cost effective to implement, based mostly on existing data, and that uses a transparent process (i.e. easy to understand) was needed by policy makers and funding agencies. This motivated Sullivan et al. (2002) to design the WPI as an alternative water situation assessment tool. The WPI has the following advantages over conventional methods:

- It is a mechanism to prioritise water needs.

- It provides a better understanding of the relationship between the physical availability of water, its ease of abstraction, and the level of welfare.

- The WPI is mainly designed to help improve the situation for people facing poor water endowments and poor adaptive capacity.

- It is a tool for monitoring progress in the water sector.

The WPI captures the whole range of issues related to water resources availability as well as their impacts on people (Sullivan et al., 2005). The primary goal was to enable holistic water- 
resource assessments on a site-specific basis at the community level. The WPI allows the use of different scales to be applied for different needs and defines water poverty according to five components. These component variables, which capture a more comprehensive picture of water management challenges (Sullivan et al., 2003), are the following:

- Resources. The availability of water, taking into account the variations in seasonal and inter-annual fluctuations and water quality.

- Access. The accessibility of water for human use taking into account the distance to a safe source and the time needed to collect the water for household and other needs including the irrigation of crops and for industrial use.

- Capacity. The ability to effectively manage water.

- Use. This captures the actual amount of water being used and extracted from the system. Use includes domestic, agricultural and industrial use (Lawrence et al., 2002).

- Environment. This variable captures the environmental impact of water management with the intention to ensure long-term ecological integrity. "Environmental factors which are likely to impact on regulation will affect capacity" (Lawrence et al., 2002:1).

A composite index approach is used to calculate the WPI (Cullis, 2005). Each of the five components consists of a number of sub-components and a weighting can be applied to each component to indicate the component's importance. The components are standardised to fall in the range 0 to 100, resulting in a final WPI value between 0 and 100 . The highest value, 100 is taken as the best situation with 0 being the worst. The purpose of the weightings is to emphasise a specific component of the WPI structure, and the importance of any component should not be predetermined by researchers as it is clearly a political decision (Sullivan, 2005).

The five key components are combined together in a general expression:

$$
W P I=\frac{w_{r} R+w_{a} A+w_{c} C+w_{u} U+w_{e} E}{w_{r}+w_{a}+w_{c}+w_{u}+w_{e}}
$$

Where

WPI = Water Poverty Index score of a particular location

$\mathrm{R}=$ Resources component (score out of 100)

$\mathrm{A}=$ Access component (score out of 100)

$\mathrm{C}=$ Capacity component (score out of 100$)$

$\mathrm{U}=$ Use component (score out of 100)

$\mathrm{E}=$ Environment component (score out of 100)

$\mathrm{w}=$ weighting factor for each component

This comprehensive approach to measuring water poverty was taken forward by researchers at the Centre for Ecology and Hydrology in Wallingford, UK. They refined the WPI that was developed by Sullivan et al. (2002) in an attempt to quantify the link between water and poverty by combing hydrological data with socio-economic data to provide a complex indicator that reflects the true nature of a community and its access to clean water (Schulze and Dlamini, 2002). These researchers, along with experts from the World Water Council, calculated the WPI for 147 countries all over the world (World Water Forum, 2003). The 
World Water Council is an independent, international organisation incorporated as a French not-for-profit association with over 250 member organisations based in over 60 countries.

South Africa scored a WPI value of 52, which places it in the lower 50\%. Considering that 100 is the perfect goal score, its score of 52 places South Africa roughly in the middle order. The majority of countries in the top ten are in the developed world, are water rich, and have extreme winters (i.e. snowfall), whereas all the countries in the lowest ten positions are in the developing world where there are relatively mild winters, and under-development plays a larger role in water poverty than the availability of the resource.

Even though other indicators were considered, for example the water scarcity index, the water resources vulnerability index, etc., they did not provide sufficient detail, especially when working on a smaller scale. A high level of detail is required to allow targeting of resources to address specific problems.

Despite the various advantages of the WPI, some criticisms have been mentioned in previous work. These criticisms include the tendency of the Access and Capacity components to have a high positive correlation with the overall WPI score, and that differences often occur between reputable estimates of the same variable (Lawrence et al., 2002). As long as the data sources are verified by the intended end-users, the differences between sources do not necessarily have to impact negatively on the efficiency of the process and the obtained map.

\section{Water poverty mapping}

Cullis (2005:8) defines water poverty mapping (WPM) as "the mapping of indicators of water poverty aggregated to a suitable spatial scale". WPM is used to identify areas of high levels of water poverty with the aim of assisting in the targeting of water-related policies to ensure the most efficient use of resources to meet the development objectives of the country. The strengths of the WPI, poverty mapping and geographic targeting are combined in WPM (Cullis, 2005).

The concept of WPM as a policy tool was introduced by Cullis (2002) by way of a small case study of the Estcourt Municipality in South Africa. In 2005 Cullis expanded the concept by constructing a water poverty map for the Eastern Cape Province in South Africa. Figure 5 is the resulting provincial water poverty map for the Eastern Cape on a municipal scale. A darker shade of blue indicates a higher WPI value for a municipality, and a lighter shade of blue indicates a lower WPI value for a municipality.

Based on the research that has been done by Cullis $(2002 ; 2005)$ on the WPI and WPM in the South African context, especially on the relevant variables to be used and different scales, his steps and processes will be used as a guideline for this research. 


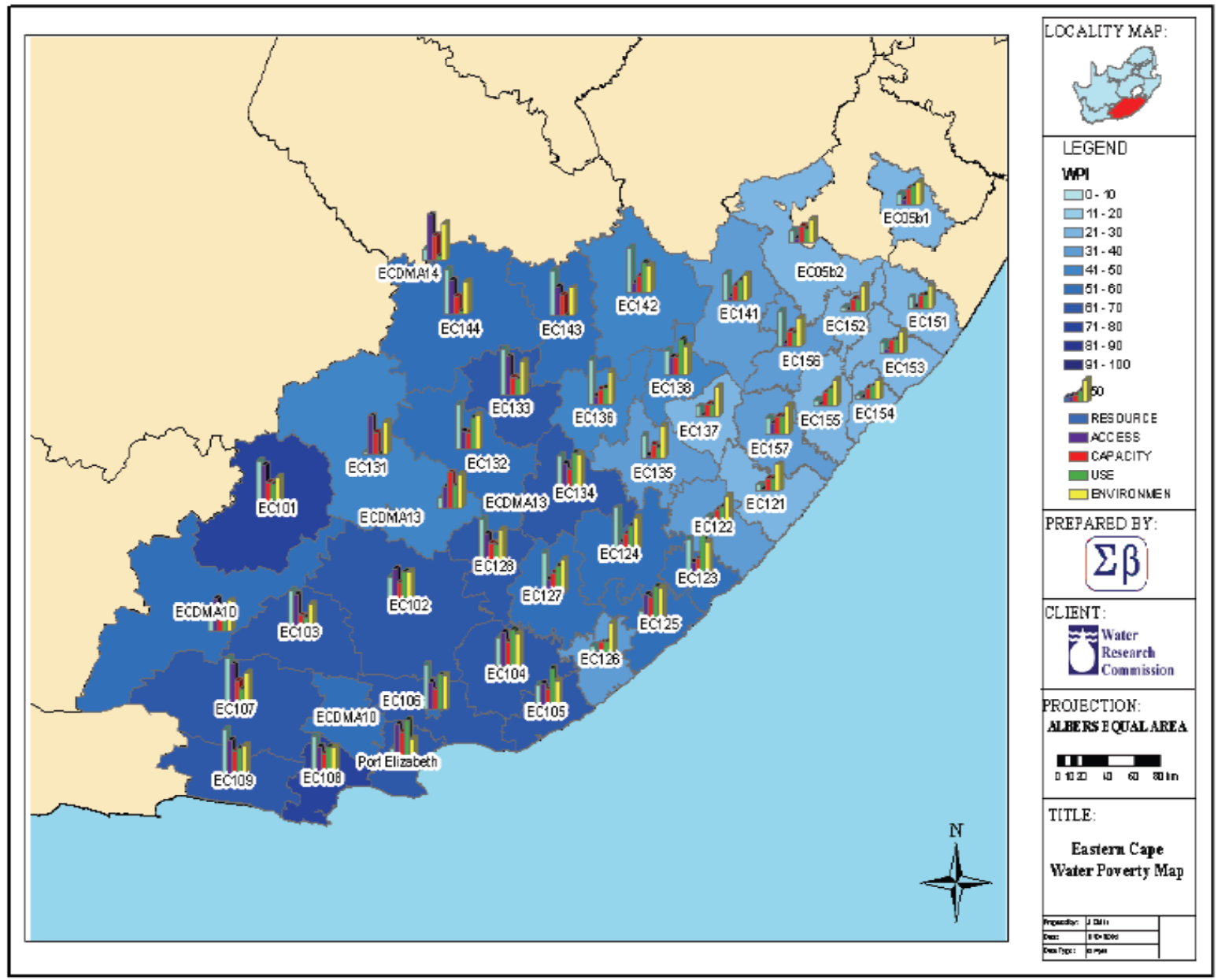

Figure 5 Provincial water poverty map on a municipal scale (Source: Cullis, 2005)

The role of water poverty maps is to monitor the water poverty in an area, and as a result to identify areas in which efforts and resources should be focused. The water poverty map can also indicate the type of intervention that would be the most appropriate. For example, if the score of the access component was the lowest in a specific area, efforts and resources should be focused on providing more access to water. WPM provides an evaluation and monitoring tool that is much more comprehensive than other water poverty indicators. As a result a great degree of efficiency is achieved in using scarce resources to meet water-related development objectives (Cullis, 2005).

\section{Data sources}

The data for this research were obtained from three sources. The first source was representatives from the local municipality and the local bulk water services provider, and the second source was the Census data from 2001, which can be accessed from the website of Statistics SA (http://www.statssa.gov.za). The third source was the Water Situation Assessment Model (or WSAM) version 5.001, which was released on 1 October 2008 and is available from the Department of Water Affairs (DWA). All the data in the WSAM were at the $98 \%$ assurance level. Table 1 lists each of the WPI components and the respective data source. 
Table 1 WPI component data sources

\begin{tabular}{|l|l|}
\hline Component & Data source \\
\hline Resource & Representatives \\
\hline Access & Census 2001 \\
\hline Capacity & Census 2001 \\
\hline Use & WSAM Version 5 \\
\hline Environment & WSAM Version 5 \\
\hline
\end{tabular}

\section{Component calculation}

\subsection{Component benchmark levels}

The five components of the WPI all have different scales and different units of measurement, and the only way in which they can be combined and compared is by converting each indicator value to an indicator score (Cullis, 2005). The ability to integrate data with different scales neatly encompasses many of the institutional, social and scientific dilemmas inherent in water management (Newson, 2009). All the components, except resource and use have absolute maximum values, whereas resource and use have optimum levels of use, with anything above or below this level adjusted accordingly.

\subsection{Component calculation}

The following sections discuss the calculation method for each of the component values, its benchmark level and the calculation of the final score that will be used to calculate the WPI. The indicators to be used for the various components as well as the benchmark levels have been selected according to the guidelines developed by Cullis (2005).

\subsubsection{Resource}

In the traditional WPI, the resource component is expressed in terms of the total surface water and groundwater resources that are available in an area, measured in $\mathrm{m}^{3} / \mathrm{c} / \mathrm{a}$ $\left(\mathrm{m}^{3} /\right.$ capita/annum). When using this measurement a minimum benchmark level (usually 0 $\mathrm{m}^{3} / \mathrm{c} / \mathrm{a}$ ) has to be used along with some or other maximum benchmark level. To obtain the final resource component score the resource component value is then merely expressed as a percentage of the maximum benchmark level.

Every five years the bulk water service providers undergo a process whereby they acquire a permit from the DWA. The permit states how much water they may extract from the water system, and this amount is based on ensuring that the sustainability of the resource is not jeopardised and that they will be able to meet the demand for water in the area. The local water services provider has just completed this process, and according to the latest figures, they are extracting about $90 \%$ of their allowance. The service provider has also made provision for a $2 \%$ annual growth rate, which means that they will be using $100 \%$ of their allowance by the time they have to renew their permit.

Representatives from both the local municipality and the local water services provider suggested that the total resource availability in an area in terms of groundwater and surface water availability is an irrelevant method for the Vaal Triangle area. It was felt that it is an irrelevant method because merely looking at total resource availability does not consider the 
state (or pollution levels) of the resource and because no groundwater is used to meet the demand for water in the area. The method suggested by the representatives is motivated firstly by the fact that it is the method currently used by management when considering the total resource availability, and secondly because it is a method that supports prediction. It requires that the resources of the area should rather be expressed in terms of what percentage of the water that the service provider may extract from the water system is actually extracted.

Due to the sensitive nature of the actual figures, the input for this component will be the percentage of the allowance that is actually extracted. The minimum benchmark level for this component is 0 and the maximum benchmark level is 100 . The value of the optimum extraction rate has been set at $90 \%$, as this is the current extraction rate that satisfies the total demand.

A resource component score of 100 indicates an optimum extraction rate of $90 \%$. Any value above or below this optimum level is adjusted so that it reflects consumption in terms of a percentage of the optimum level. Table 2 shows the resource component scores for each of the three towns (as obtained from a representative from the local bulk water services provider).

Table 2 Resource component calculation

\begin{tabular}{|l|l|l|}
\hline & $\begin{array}{l}\text { Value } \\
\text { (Extraction rate \%) }\end{array}$ & $\begin{array}{l}\text { Score } \\
\mathbf{( \% )}\end{array}$ \\
\hline Vanderbijlpark & 90 & 100 \\
\hline Vereeniging & 90 & 100 \\
\hline Sasolburg & 90 & 100 \\
\hline
\end{tabular}

The values for the three towns under consideration are the same because all three towns get their water from the same water system.

\subsubsection{Access}

The access component value is calculated as:

$$
\mathrm{A}=\frac{\text { Households withaccess to secure water source }}{\text { Totalhouseholds }}
$$

A secure water source is defined as being piped water either inside the dwelling or inside the yard. This study is limited to these two sources of water because there are too many factors influencing access to a communal water source. Some of these factors include limited access due to a large number of households using the communal source and certain community factions monopolising the facility. This would not provide individuals with sufficient control over their water supply (Cullis, 2005).

The minimum benchmark level for access is $0 \%$, and the maximum level is $100 \%$ as access expresses the percentage of people with access to a safe water source. Table 3 gives the access component scores for each of the three towns (as obtained from Census data). 
Table 3 Access component calculation

\begin{tabular}{|l|l|l|l|l|}
\hline & $\begin{array}{l}\text { Households with Safe } \\
\text { Water Source }\end{array}$ & $\begin{array}{l}\text { Total } \\
\text { Households }\end{array}$ & $\begin{array}{l}\text { Value } \\
\text { (Households with } \\
\text { Safe Water Source / } \\
\text { Total Households) }\end{array}$ & Score (\%) \\
\hline Vanderbijlpark & 25422 & 26602 & 0.955 & 95.564 \\
\hline Vereeniging & 21103 & 22884 & 0.922 & 92.217 \\
\hline Sasolburg & 7456 & 7644 & 0.975 & 97.541 \\
\hline
\end{tabular}

\subsubsection{Capacity}

The capacity component consists of educational capacity as well as income capacity. The educational capacity value is calculated as:

$\mathrm{EC}=\frac{\text { People with education greater than grade } 4}{\text { Urban population }}$

and the income capacity value is calculated as:

$\mathrm{IC}=\frac{\text { Households withincome greater than R26 } 400 \text { per annum }}{\text { Totalhouseholds }}$

In previous work done by Cullis (2005) for the Eastern Cape Province, it was determined that grade 4 is the educational level at which information regarding responsible water use is disseminated to learners. As the same education plan is still in place, grade 4 will be used as the threshold level for educational capacity. According to the WSDP (the Water Service Development Plan which is available from the DWA), the average person is willing to spend roughly $5 \%$ of their disposable income on services. After discussions with a local municipality representative it was determined that a basic suite of services costs approximately R110 per household per month, or R1 320 per household per year. If R1 320 equals 5\% of disposable income, 100\% will equate to R26 400, the threshold level for income capacity.

Based on previous work done by Cullis $(2002$; 2005) in South Africa, the two subcomponents used for the capacity component have been assigned equal importance (weighting). The capacity component value is therefore merely the average of the two subcomponents, and is calculated as:

$C=\frac{E C+I C}{2}$

The minimum benchmark level for capacity is $0 \%$, and the maximum level is $100 \%$. The levels have been set at 0 and 100 as capacity expresses the percentage of people with a certain education level and the number of households with a certain income level. Table 4 gives the capacity component scores for each of the three towns (as obtained from Census data). 
Table 4 Capacity component calculation

\begin{tabular}{|l|l|l|l|l|l|l|l|}
\hline & $\begin{array}{l}\text { People with } \\
\text { Education > } \\
\text { Grade 4 }\end{array}$ & $\begin{array}{l}\text { Total } \\
\text { Population }\end{array}$ & $\begin{array}{l}\text { Education } \\
\text { Capacity } \\
\mathbf{( \% )}\end{array}$ & $\begin{array}{l}\text { Households } \\
\text { with } \\
\text { Income } \\
\text { R26 400 }\end{array}$ & $\begin{array}{l}\text { Total } \\
\text { Households }\end{array}$ & $\begin{array}{l}\text { Income } \\
\text { Capacity } \\
(\mathbf{\%})\end{array}$ & $\begin{array}{l}\text { Score } \\
\mathbf{( \% )}\end{array}$ \\
\hline VdB-Park & 63529 & 474081 & 13.4 & 18432 & 26602 & 69.288 & 41.344 \\
\hline Vereeniging & 58649 & 497600 & 11.786 & 15135 & 22884 & 66.14 & 38.963 \\
\hline Sasolburg & 19906 & 141000 & 14.118 & 6220 & 7644 & 81.371 & 47.745 \\
\hline
\end{tabular}

In its Integrated Development Plan (IDP) for 2009/2010, the ELM have identified the following constraints with regard to economic growth in the area (ELM, 2010):

1. Population growth has continuously been higher than economic growth, which leads to a decrease in the standard of living.

2. The level of socio-economic disparity between population groups is high, with pockets of severe poverty to be found.

3. The municipality has to compete harder with more centrally located areas for new investment, owing to its relative distance from the core of the Gauteng province.

\subsubsection{Use}

The use component value is calculated as:

$\mathrm{U}=\frac{\text { Direct requirement urban }}{\text { Urban population }} * \frac{10^{9}}{365} \mathrm{l} / \mathrm{c} / \mathrm{d}$ (litres/capita/day).

The minimum benchmark levels for the use component are $01 / \mathrm{c} / \mathrm{d}$ and $3201 / \mathrm{c} / \mathrm{d}$ (as an optimum level is used), and according to Cullis (2005) the maximum (optimum) level for use in the South African environment is $160 \mathrm{l} / \mathrm{c} / \mathrm{d}$. Although the use component reflects the average usage, it should be mentioned that although the Vaal Triangle is a summer rainfall area, the demand for water in the Vaal Triangle peaks during spring (roughly from September to November), due to gardening requirements.

A use component score of 100 indicates an optimum consumption level of $160 \mathrm{l} / \mathrm{c} / \mathrm{d}$. Any value above or below this optimum level is adjusted so that it reflects consumption in terms of a percentage of the optimum level.

As this research and WPM in general focus on residential water poverty alleviation, it is important to differentiate between residential and non-residential water use. A representative from the Emfuleni local municipality indicated that on a month-to-month basis, residential water use tends to fluctuate between $50 \%$ and $55 \%$ of the total water use, and non-residential use between $45 \%$ and $50 \%$ of the total water use. Based on the information obtained from the representative, a figure of $52 \%$ is used for residential use and a figure of $48 \%$ is used for nonresidential use.

Of the three towns under consideration, Vanderbijlpark was the only one whose use component value was not adjusted, as the major non-residential water consumer in the town 
obtains their water directly from the local bulk water services provider, instead of from the local municipality. This is, however, not the case for Vereeniging and Sasolburg, as both of these towns have major non-residential water consumers that obtain their water from the local municipality, and including them in the usage figures corrupts the use component score. In the three towns used in this study, the major non-residential water consumers are industries. Table 5 gives the use component scores for each of the three towns (as obtained from the WSAM).

Table 5 Use component calculation

\begin{tabular}{|l|l|l|l|l|}
\hline & Direct Requirement Urban & Population & Value (1/c/d) & Score (\%) \\
\hline Vanderbijlpark & 22.26 & 474081 & 128.641 & 80.401 \\
\hline Vereeniging & 25.896 & 497600 & 142.58 & 89.113 \\
\hline Sasolburg & 10.598 & 141000 & 205.926 & 71.296 \\
\hline
\end{tabular}

\subsubsection{Environment}

The environment component value is obtained directly from the WSAM, and no calculation is required to determine the component value.

The minimum benchmark level for environment is 0 , and the maximum level is 5 . These minimum and maximum levels are appropriate as it is the exact measurement scale used by the DWA to express the Present Ecological Class (PEC) in the WSAM. According to Fuggle and Rabie (2009), the attributes that the DWA use to determine the PEC in the WSAM include flow characteristics, inundation, water quality, stream bed condition, introduced stream bed biota and riparian condition.

The environment component score is then calculated by multiplying the component value by 20 , as this expresses the component as a score out of 100, and therefore as a percentage. Table 6 shows the environment component scores for each of the three towns (as obtained from the WSAM).

Table 6 Environment component calculation

\begin{tabular}{|l|l|l|}
\hline & Index (Rating) & Score (\%) \\
\hline Vanderbijlpark & 4.086 & 81.72 \\
\hline Vereeniging & 3.641 & 72.82 \\
\hline Sasolburg & 3.856 & 77.12 \\
\hline
\end{tabular}

Obtained from the WSAM, which is available from the DWA

\section{Component weighting}

The option of adding different weightings to the components have been included in the WPI to compensate for different priorities and circumstances depending on the area or region for which the WPI calculation is performed. When deciding which weightings to use for the calculation of the WPI, the three broad descriptors that need to be considered for the area under consideration include hydrological conditions, economic conditions, and national/regional priorities. The intended use of the obtained WPI and accompanying water 
poverty map will dictate the specific descriptors that have to be used. Table 7 contains the various weighting groupings, as compiled by Sullivan et al. (2002).

Table 7 Weighting options for the WPI

\begin{tabular}{|l|l|l|l|l|l|l|l|}
\hline \multicolumn{2}{|l|}{ Local condition descriptors } & \multicolumn{3}{l|}{ Component weights } \\
\hline $\begin{array}{l}\text { Hydrological } \\
\text { condition }\end{array}$ & $\begin{array}{l}\text { Economic } \\
\text { condition }\end{array}$ & $\begin{array}{l}\text { National } \\
\text { priorities }\end{array}$ & Resource & Access & Capacity & Use & Environment \\
\hline Very good & Unknown & $\begin{array}{l}\text { Agriculture, } \\
\text { Industry \& } \\
\text { Social } \\
\text { Development }\end{array}$ & 1 & 2 & 2 & 3 & 1 \\
\hline Average & Average & $\begin{array}{l}\text { Social } \\
\text { Development }\end{array}$ & 1 & 2 & 2 & 1 & 1 \\
\hline Very good & Good & $\begin{array}{l}\text { Environment } \\
\text { \& Social } \\
\text { Development }\end{array}$ & 1 & 2 & 2 & 1 & 2 \\
\hline Unknown & Unknown & $\begin{array}{l}\text { Industry \& } \\
\text { Agriculture }\end{array}$ & 1 & 2 & 2 & 2 & 1 \\
\hline
\end{tabular}

This table is not exhaustive and can be adapted as required based on the hydrological condition, economic condition and national priorities of a specific region. Only four combinations have been given as these combinations have been prevalent in other studies on the WPI and WPM (see Sullivan et al. (2002), Cullis (2002; 2005)). The second grouping of weightings will be used ( 1 for resource, 2 for access, 2 for capacity, 1 for use and 1 for environment) as the descriptors that are related to the chosen weightings are the closest match to the conditions found in the area under consideration.

\section{Water poverty index calculation}

After calculating each of the individual component scores, the weightings have to be used to calculate the final WPI for each town. The formula to be used for the final calculation of the WPI is given below.

$$
W P I=\frac{w_{r} R+w_{a} A+w_{c} C+w_{u} U+w_{e} E}{w_{r}+w_{a}+w_{c}+w_{u}+w_{e}}
$$

Therefore the WPI for Vanderbijlpark is:

$$
W P I=\frac{(1 * 100)+(2 * 95.564)+(2 * 41.344)+(1 * 80.401)+(1 * 81.72)}{1+2+2+1+1}=76.562,
$$

the WPI for Vereeniging is:

$$
W P I=\frac{(1 * 100)+(2 * 92.217)+(2 * 38.963)+(1 * 89.113)+(1 * 72.82)}{1+2+2+1+1}=74.899
$$


and the WPI for Sasolburg is:

$$
W P I=\frac{(1 * 100)+(2 * 97.541)+(2 * 47.745)+(1 * 71.296)+(1 * 77.12)}{1+2+2+1+1}=76.998
$$

Table 8 summarises the WPI for each of the three towns in tabular form.

Table 8 WPI calculation

\begin{tabular}{|l|l|l|l|l|l|l|}
\hline & $\begin{array}{l}\text { Resource } \\
\text { (Weighting=1) }\end{array}$ & $\begin{array}{l}\text { Access } \\
\text { (Weighting=2) }\end{array}$ & $\begin{array}{l}\text { Capacity } \\
\text { (Weighting=2) }\end{array}$ & $\begin{array}{l}\text { Use } \\
\text { (Weighting=1) }\end{array}$ & $\begin{array}{l}\text { Environment } \\
\text { (Weighting=1) }\end{array}$ & WPI \\
\hline Vanderbijlpark & 100 & 95.564 & 41.344 & 80.401 & 81.72 & 76.562 \\
\hline Vereeniging & 100 & 92.217 & 38.963 & 89.113 & 72.82 & 74.899 \\
\hline Sasolburg & 100 & 97.541 & 47.745 & 71.296 & 77.12 & 76.998 \\
\hline
\end{tabular}

As mentioned earlier, when working with WPM and the WPI, the contributions of each of the components to the final index value is just as important as the final index value itself. Figure 6 is a graphical representation of the component contributions and water poverty indices of the three towns in the Vaal Triangle.

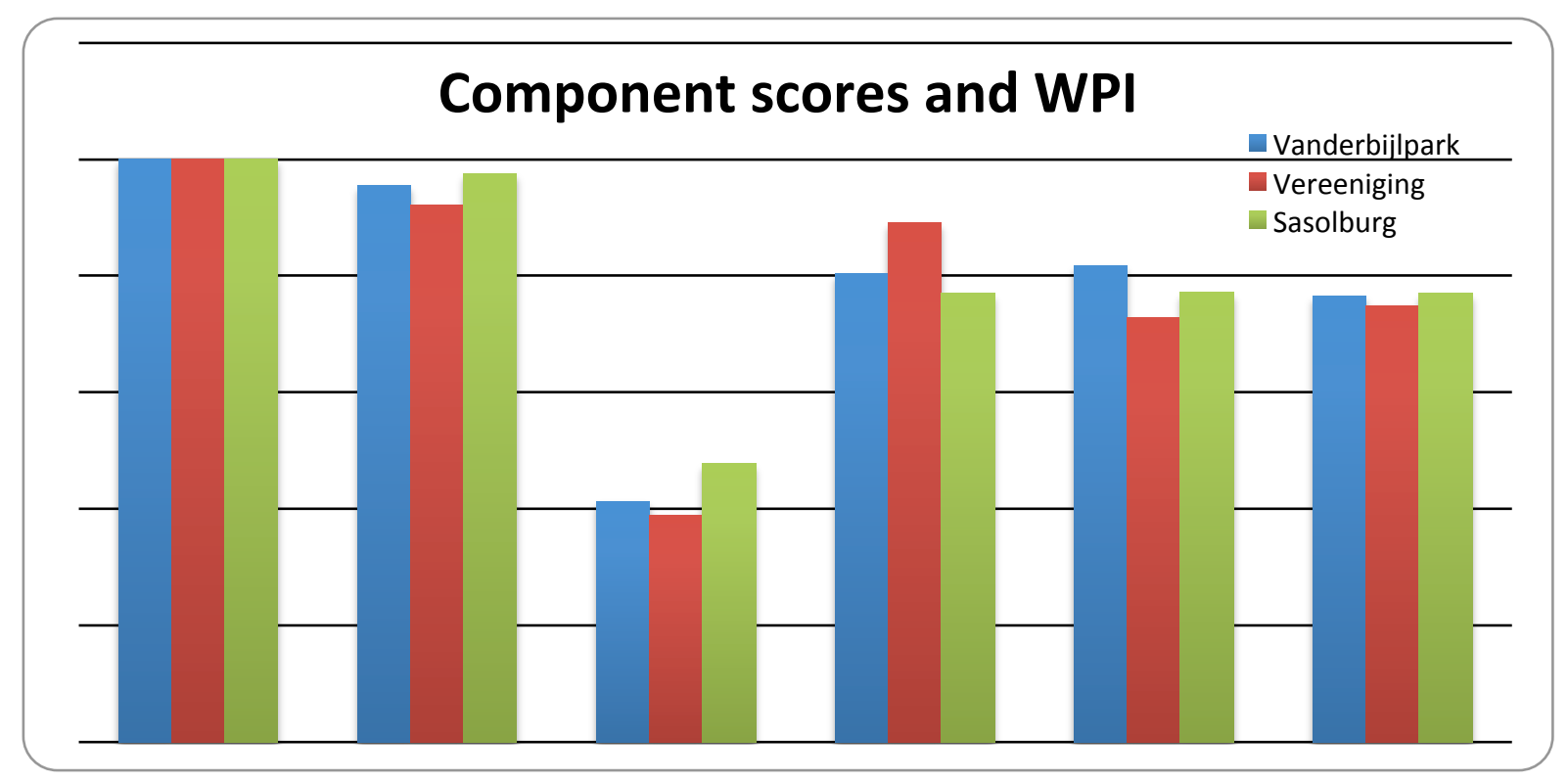

Figure 6 Graphical representation of component scores and WPI

The three towns in this study all have a WPI in the high seventies, which is relatively high in comparison with the entire country, which has a WPI of only 52. The capacity component score was the lowest of all the components for each of the three towns in the study, mainly 
due to extremely low education level figures. Therefore improving educational capacity in each of the towns should be the priority for improving the water poverty in the region.

\section{Map construction}

One of the major advantages of WPM is that it provides a visual representation of the WPI. Any map can be used, as long as it is reliable and accurate, and it adheres to the required scale. After calculating the various water poverty indices, the next step in the process is to construct the water poverty map. For the purpose of this study, the image of the area under consideration was obtained from Google Earth, and the mapping was done using Map Maker version 3.5. The WPI was plotted on the map, and the resulting water poverty map is represented in figure 7 .

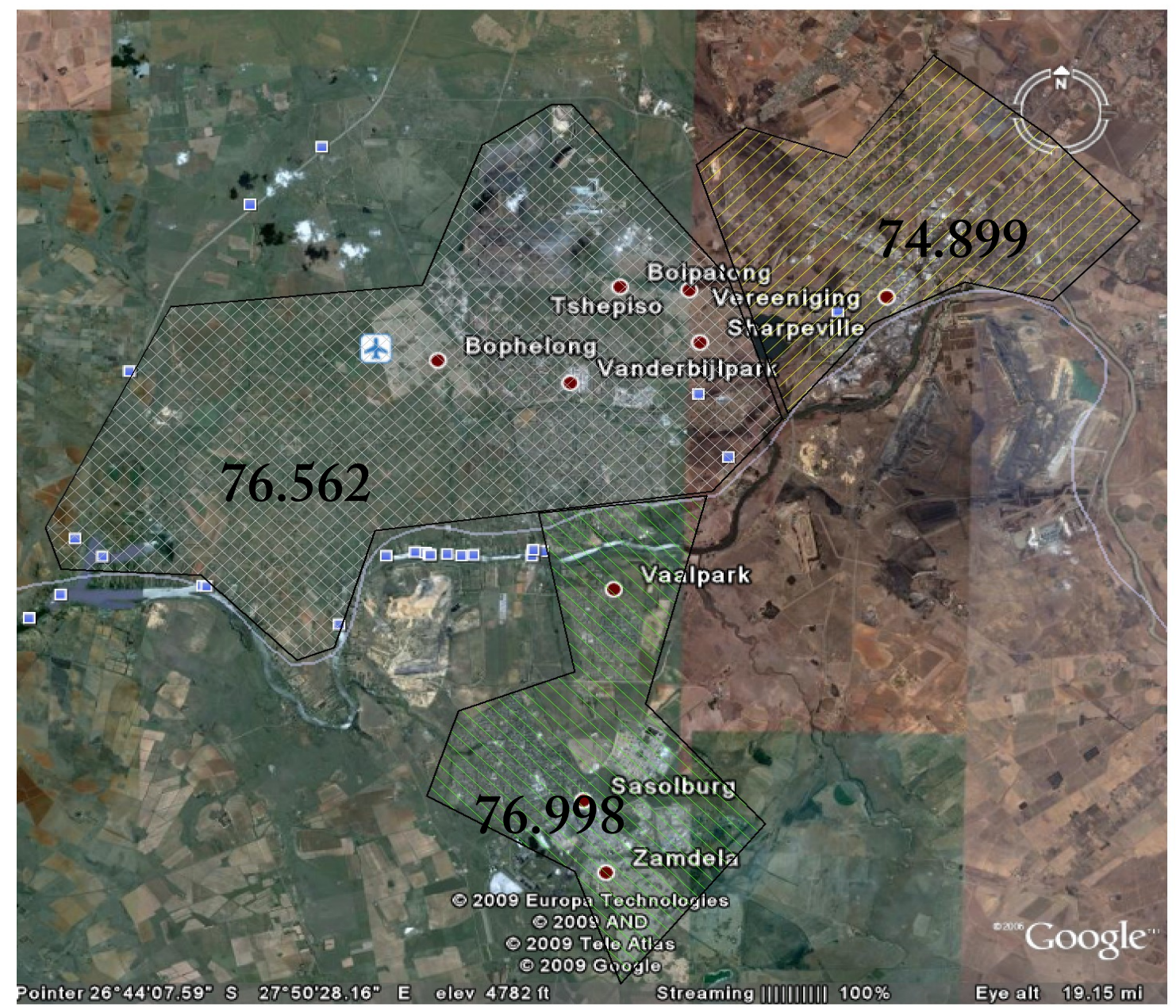

Figure 7 Water poverty map for the Vaal Triangle

On the map the various colours indicate the boundaries of the three towns, namely Vanderbijlpark: white, Vereeniging: yellow and Sasolburg: green. The three numbers on the map represent the water poverty indices for each of the towns. 


\section{Recommendations}

When planning for the future, local municipalities, water service providers and governments have to ensure that they can keep up with growth and development. This is particularly important when it comes to water and the demand for water, as it is an extremely valuable but also very limited resource. The following three subsections will describe how the local municipality, the bulk water service provider of the area under consideration, and the government currently make and use their water demand predictions, and how water poverty maps and WPM can be used to improve the process and the accuracy of the predictions.

\subsection{Recommendations to local municipalities}

A local municipality has to predict its future water requirements on a regular basis. These predictions are given to the water services provider so that they can ensure that they have everything in place to meet the demand for water.

Currently these predictions are based on two measurements: the trend of demand for water and the population growth rate. The demand and the growth figures are available on a month-to-month basis, and when determining the value for the prediction, the average of the two measurements is used. This process only changes if it is known beforehand that an intervention will occur or that major changes will be made to the system or infrastructure. An example of both an intervention and a major change to the system that occurred recently in the municipality's area of governance was the introduction of a pressure station (obtained from an interview with a representative from the Emfuleni local municipality). Pressure stations are used in areas where a lot of water is wasted, either through leaks or irresponsible usage. Pressure stations cause a decrease in the water pressure during times of low usage, typically between 22:00 and 5:00. The municipality took this intervention and associated water saving into account when they made their most recent prediction. During the investigation that was conducted by the local municipality, loss due to leakage (also referred to as non-revenue water, or NRW) was estimated to be in the region of $31 \%$. This is a significant figure which indicates that almost a third of the water that the municipality is being billed for is being wasted. According to Sharma and Vairavamoorthy (2009), the average amount of NRW in developing countries in Africa and Asia tends to vary between 20 $-70 \%$. As the current method for determining individual usage does not consider this loss factor, and is therefore less accurate, the following formula was developed as part of this research to more accurately determine individual usage by compensating for the loss factor. It was derived by incorporating two changes to the formula suggested by Sullivan et al. (2002). The original formula calculated a yearly usage figure, whereas the derived formula can be used to calculate a specific monthly usage figure, which facilitates more accurate analysis, and the second change was the introduction of the loss factor into the equation, as discussed above. This formula can be used for expressing use on its own as well as for expressing use in the WPI and the accompanying water poverty map.

$$
\text { Use }=\frac{\text { Total Kilolitres Billed } * 1000}{\text { Total Population } / \text { Days in Month }} *(1-\text { Loss Factor })
$$


Predicting future water requirements to ensure an adequate supply is only one of the purposes of the short-term demand predictions. These demand predictions are also used when determining the relevant tariff that the end user will be charged. In the long-term these predictions are used to plan ahead for projects such as infrastructure improvement, maintenance, expansion, etc.

The result of an investigation into the processes of the local municipality was that the use component of the WPI and the water poverty map can immediately form part of their predictions, and that if water poverty maps can be constructed at regular intervals they would even have the potential to completely replace the current prediction system. The use component can either replace the current method of looking at overall demand, or it can be used as a verification tool. Currently, when determining overall demand, the municipality looks at the total number of $\mathrm{Kl}$ that was supplied to them by the water services provider. Unfortunately this total also contains the water that has been lost, for example through leaking pipes, and this affects the accuracy of the information. By multiplying the usage (measured in $1 / \mathrm{c} / \mathrm{d}$ ) as calculated from the formula given above with the population size, it can be used as a more accurate measure of overall demand. Alternatively it can be used to confirm whether the overall demand obtained earlier is reasonably accurate or not. It was also highlighted that if water poverty maps were constructed on a relatively regular basis, perhaps monthly or even every two months, using the most up-to-date data, the maps could become the sole basis of the municipality's predictions. A series of regularly constructed maps will make it much easier to measure the impacts of development, which will also provide users with a relevant and up-to-date overall picture, taking into consideration not only the resource, but also the factors influencing its responsible usage.

In municipalities that are responsible for their own water supply, i.e. that do not obtain their water from a bulk water services provider, accurate predictions are even more important. If these municipalities do not have an adequate supply, the impact is far reaching, as they cannot simply request more water from the provider, and this in turn places an even greater strain on their perhaps already stressed infrastructure. During the consultation it was highlighted that water poverty maps can be especially useful to these municipalities as they have a far greater responsibility for ensuring a sustainable water supply. However, all municipalities can benefit when predicting the impact on demand caused by changing volumes due to the introduction and expansion of water and sanitation.

In addition to being able to predict future water demand (using any method), it is also important to have a very accurate indication of what infrastructure is currently in place, and what will have to be done to ensure that future demand can be met.

A master plan is a document that a municipality has to compile for every developed area under its jurisdiction, which describes the intentions of the municipality with regards to service delivery specifically. It is typically a document that is compiled during the first few years after a town has been established, and which is then updated on a regular basis. In the master plan areas are classified as being either urban, urban-edge or rural. The urban-edge is usually the area where a town expands, and therefore the urban-edge of a town shifts continuously. The water poverty map itself can be used to keep track of the town boundaries as well as the areas that have been classified according to the three different classifications.

The master plan serves two main purposes. Firstly, it gives a detailed description of what is currently available (in terms of infrastructure, etc.), and secondly what the current demand is and what will be needed to ensure that the demand can be sustainably met. 
The result of an investigation into the processes of the local municipality was that the resource component of the water poverty map can be used as part of the master plan to guide development. The resource component will give a very clear indication of how much development is viable given the current maximum carrying capacity, in other words when the maximum level will be reached. The main limiting factor on development (suggested planned development) is resource availability, and one can plan as much as one likes, but water is and will always be a finite resource. Therefore, to ensure the relevance and accuracy of the master plan, one must ensure that it is informed through the use of the most up-to-date information available.

WPM can also play a crucial role in a municipality's Integrated Development Plan (or IDP). The IDP is similar to the master plan, with the major difference being that the IDP describes all the factors surrounding development for a region over the short to medium term, not only service delivery as is the case with the master plan. The benefits of the WPI and WPM for this document will be similar to that of the master plan.

\subsection{Recommendations to water service provider}

Water services providers need to consider all the predictions from the municipalities they serve when preparing their projections for government. Although they annually predict the demand for the coming year, every five years they have to predict the demand for the following five years when they apply for their permit from the DWA. The permit they obtain from the DWA firstly gives them permission to extract water from the system, and secondly it states how much water they are allowed to extract. The advantages of the use of water poverty maps by the water services providers is similar to those experienced by local municipalities, the only difference being the scale at which the water poverty map is constructed.

\subsection{Government}

When it comes to the government and the responsible state department, the advantages of more accurate predictions increase ten-fold. Government has to ensure that it can meet the water demand of its people, and to enable this accurate predictions are needed so that they can have a clear idea of when the demand is going to overtake the supply. The sooner they know when this is likely to happen, the more time they have to look for alternatives. In recent years one such alternative that has been implemented was the first phase of the Lesotho Highlands Water Scheme (Du Toit De Villiers et al., 1996). It feeds water directly from the Lesotho Highlands into the Vaal Dam. If the demand for water keeps increasing at its current rate, it is foreseen that the second phase of the scheme will have to be implemented within the next decade. Other incentives and initiatives that have been initiated and supported by government in an effort to decrease the total water demand include, amongst others, the National Waterwise Campaign, training of communities to make people more water wise, installing water saving devices where possible, providing incentives to water users to use less water, municipal bylaws, and regulations, guidelines and standards to make bathroom accessories and white appliances more water efficient (DWAF, 2008).

At the level of provincial government, water poverty maps at municipal level can be used to identify the municipalities or districts most in need of an intervention. This information can then be used when assigning resources to ensure that the water poverty is addressed efficiently. On a national level the benefits of WPM are similar. The maps can be constructed 
at a provincial level to identify the province with the highest water poverty. Once the province has been identified, a map on a smaller scale can be used to identify the worst district in that province, and from there a map on an even smaller scale can be used to identify the worst municipality in that district.

\section{Conclusion}

The WPI and WPM have various advantageous applications for local municipalities, bulk water service providers and government, both local and national. The maps can assist with water poverty alleviation, improving the accuracy of predictions of future water demand, and for assisting with planning for the future in terms of infrastructure development and maintenance. As long as the appropriate scale, relevant variables and intended use is clear from the beginning of the process, the obtained indices and map can assist with achieving a variety of goals. As soon as its relevance and importance becomes widely accepted by water practitioners and those in management positions, more efficient use of our already scarce water resources will receive a major boost, thereby ensuring sufficient supply for the future.

\section{References}

Ahmad, Q. K. 2003. Towards poverty alleviation: the water sector perspectives, Water Resources Development, 19(2), pp. 263-277.

Clarke, R. \& King, J. 2004. The Atlas of Water. Mapping the world's most critical resource. Earthscan, 8 - 12 Camden High Street, London, NW1 0JH, United Kingdom.

Cullis, J. D. S. 2002. Targeting the Water Poor through Water Poverty Mapping: A Case study using Census Data and the Water Poverty Index for the Estcourt Municipal District, South Africa. Unpublished M.Sc. Thesis, Environmental Change Institute, Oxford University Press.

Cullis, J. D. S. 2005. Water poverty mapping: development and introduction using a case study at the local municipal scale for the Eastern Cape. Water Research Commission, TT 250/05, August.

Denscombe, M. 2003. The Good Research Guide, $2^{\text {nd }}$ Edition. Open University Press, 325 Chestnut Street, Philadelphia, PA 19106, USA.

Department of Water Affairs and Forestry. 2008. Integrated Sector Support and Improved Sustainability within Water for Growth and Development. Presentation to the National Water Summit on 17 March 2008.

Doolan, D. M. \& Froelicher, E. S. 2009. Using an Existing Data Set to Answer New Research Questions: A Methodological Review. Research and Theory for Nursing Practice: An International Journal, 23(3), pp. 203 - 215.

Du Toit De Villiers, G., Schmitz, P. M. U. \& Booysen, H. J. 1996. South Africa's Water Resources and the Lesotho Highlands Water Scheme: A Partial Solution to the 
Country's Water Problems. Water Resources Development, 12(1), pp. 65 - 77.

Emfuleni Local Municipality (ELM). 2010. Integrated Development Plan 2009/10.

Fuggle, R. F. \& Rabie, M. A. 2009. Environmental Management in South Africa, $2^{\text {nd }}$ Edition. Juta Law, 7 Mercury Crescent, Hillstar, Wetton, 7780, Cape Town.

Galliers, R. D. \& Land, F. F. 1987. Choosing Appropriate Information Systems Research Methodologies. Communications of the ACM, 30(11), pp. 900 - 902.

Global Water Partnership. 2000. Towards water security: a framework for action, Stockholm, Global Water Partnership.

Hemson, D., Kulindwa, K., Lein, H. \& Mascarenhas, A. 2008. Poverty and Water. Explorations of the reciprocal relationship. Zed Books Ltd, 7 Cynthia Street, London, N1 9JF, United Kingdom.

Holland, A. S. 2005. The water business. Corporations versus people. Zed Books Ltd, 7 Cynthia Street, London, NI 9JF, United Kingdom.

Langford, M. 2005. The United Nations concept of water as a human right: a new paradigm for old problems? Water Resources Development, 21(2), pp. 273 - 282.

Lawrence, P., Meigh, J. \& Sullivan, C. 2002. The water poverty index: an international comparison. Keel Economics Research Papers, KERP 2002/19, October, 2002.

Melville, S. \& Goddard, W. 1996. Research Methodology. Juta \& Co Limited, P.O. Box 14373, Kenwyn, 7790.

Meyer, W. N. 2007. The economics of water, water for life; sanitation for dignity. Van Schaik Publishers, 1064 Arcadia Street, Hatfield Pretoria.

Newson, M. 2009. Land, Water and Development. Sustainable and adaptive management of rivers, 3rd Edition. Routledge, 2 Park Square, Milton Park, Abingdon, Oxon, OX14 $4 \mathrm{RN}$.

Onwuegbuzie, A. J. \& Leech, N. L. 2005. On Becoming a Pragmatic Researcher: The Importance of Combining Quantitative and Qualitative Research Methodologies. International Journal of Social Research Methodology, 8(5), pp. 375 - 387.

Pallett, J. 1997. Sharing water in Southern Africa. Desert Research Foundation of Namibia, PO Box 20232, Windhoek, Namibia.

Perveen, S. \& James, L. A. 2011. Scale invariance of water stress and scarcity indicators: Facilitating cross-scale comparisons of water resources vulnerability. Applied Geography, 31(2011), pp. 321 - 328.

Rand Water. 2008. http://www.wisa.org.za/patrons/randwater/index2.html [2 October 2008].

Rijsberman, F. R. 2005. Water scarcity: Fact or fiction? Agricultural Water Management, 80(2006), pp. $5-22$.

Schulze, R. E. \& Dlamini, D. J. M. 2002. Mesoscale Indicators of Water Poverty in the Thukela Catchment, South Africa, under baseline land cover conditions. Appendix 9.14 to Sullivan, C. A., Meigh, J. R., Fediw, T. S. Derivation and Testing of the Water Poverty Index Phase 1: Final Report. DFID. 
Sharma, S. K. \& Vairavamoorthy, K. 2009. Urban water demand management: prospects and challenges for the developing countries. Water E Environment Journal, 23(3), pp. 210 -218 .

Sullivan, C. A., Meigh, J. R. \& Fediw, T. S. 2002. Derivation and Testing of the Water Poverty Index Phase 1: Final Report. DFID.

Sullivan, C. A. 2002. Calculating a Water Poverty Index. World Development, 30(7), pp. 1195 -1210 .

Sullivan, C. A, Meigh, J. R. \& Lawrence, P. 2005. Application of the Water Poverty Index at different scales: a cautionary tale. Water International, Vol. 31(3), pp. 412 - 426.

Sullivan, C. A., Meigh, J. R., Giacomello, A. M., Fediw, T., Lawrence, P., Samad, M., Mlote, S., Hutton, C., Allan, J. A., Schulze, R. E., Dlamini, D. J. M., Cosgrove, W., Delli Priscoli, J., Gleick, P., Smout, I., Cobbing, J., Calow, R., Hunt, C., Hussain, A., Acreman, M. C., King, J., Malomo, S., Tate, E. L., O'Regan, D. P., Milner, S. \& Steyl, I. 2003. The Water Poverty Index: Development and application at the community scale. Natural Resources Forum, 27, pp. 1-11.

Swanson, R. A. \& Holton, E. F. $3^{\text {rd }}$. 2005. Research in organizations: Foundations and methods of inquiry. San Francisco, Berrett-Koehler.

Swatuk, L. A. 2010. The State and Water Resources Development through the Lens of History: A South African Case Study. Water Alternatives, Vol. 3(3), pp.521 - 536.

Warfield, D. 2010. IS/IT Research: A Research Methodologies Review. Journal of Theoretical and Applied Information Technology, 13(1/2), pp. $28-35$.

World Water Forum. 2003. Water Poverty Index Yields Surprising Results. 3rd World Water Forum press release. 